\title{
Association of T Cell and Macrophage Activation with Arterial Vascular Health in HIV
}

\author{
Heather N. Grome, Louise Barnett, Cindy C. Hagar, \\ David G. Harrison, ${ }^{3,4}$ Spyros A. Kalams, ${ }^{2,5}$ and John R. Koethe ${ }^{2}$
}

\begin{abstract}
HIV-infected individuals are at increased risk of cardiovascular disease (CVD), but the arterial vascular functions affected by persistent innate and cellular immune activation are not well described. We assessed the relationship between immunologic and vascular parameters in $70 \mathrm{HIV}$-infected adults on efavirenz, tenofovir, and emtricitabine with more than 2 years of virologic suppression and no history of CVD. We measured brachial artery flowmediated dilation (FMD) using ultrasound and circulating intercellular adhesion molecule 1 (ICAM-1) and vascular cell adhesion molecule 1 (VCAM-1) by multiple immunoassay. We also measured circulating naive $\left(\mathrm{CD} 45 \mathrm{RO}^{-} \mathrm{CCR} 7^{+} \mathrm{CD} 27^{+}\right)$, activated $\left(\mathrm{CD} 38^{+}\right.$and $\left.\mathrm{CD} 38^{+} \mathrm{DR}^{+}\right)$, exhausted $\left(\mathrm{PD} 1^{+}\right)$, senescent $\left(\mathrm{CD} 57^{+}\right)$, and memory $\left(\mathrm{CD} 45 \mathrm{RO}^{+}\right) \mathrm{CD}^{+}$and $\mathrm{CD} 8^{+} \mathrm{T}$ cell subsets by flow cytometry, and macrophage activation markers by ELISA and multiple immunoassay. Regression models were adjusted for age, sex, smoking, duration of antiretroviral therapy (ART), and body mass index. Median age was 45 years (IQR 39, 50), median CD4 ${ }^{+}$count $701 \mathrm{cells} / \mu \mathrm{l}$ (IQR 540, 954), and $43 \%$ were female. Lower brachial FMD was associated with a higher percentage of activated CD $8^{+}$ T cells $(p<.01)$, but not associated with macrophage activation. In contrast, higher ICAM-1 and VCAM-1 were associated with sCD163 ( $p<=.01$ for both), macrophage inflammatory protein- $1 \alpha$ ( $p<=.02$ for both), and sCD14 ( $p=.01$ for ICAM-1 only). These findings are consistent with the hypothesis that circulating $\mathrm{CD} 8^{+} \mathrm{T}$ cell activation may impair arterial smooth muscle relaxation, while macrophage activation has a role in the expression of endothelial cell proteins involved in immune cell translocation. Both innate and cellular immune activation appear to promote arterial vascular disease in HIV-infected persons on ART using differing mechanisms.
\end{abstract}

Keywords: HIV, cardiovascular, immune activation, flow-mediated dilation, endothelium

\section{Introduction}

$\mathbf{H}$ IV INFECTION IS ASSOCIATED WITH increased risk of cardiovascular disease (CVD), including acute MI, stroke, and peripheral artery disease. ${ }^{1-4}$ This finding persists even after adjustment for standard risk factors such as age, sex, and smoking status. ${ }^{4,5}$ While the etiology of CVD risk is multifactorial, increased vascular endothelial activation and impaired smooth muscle function is a feature of HIV infection that persists despite viral suppression with antiretroviral therapy (ART). ${ }^{6,7}$ These changes in vascular health likely play a role in the development of CVD by promoting atherosclerosis and plaque formation. ${ }^{8}$
Arterial blood vessels are a complex physiologic system comprising specialized endothelial cells, vascular smooth muscle cells, and cells of the adventitia, which regulate vascular tone, circulating cell adhesion and transmigration, tissue repair, and related homeostatic processes. ${ }^{9}$ HIV infection can upset this delicate equilibrium through direct viral effects and the promotion of a persistent state of cellular immune activation and inflammation despite suppression of plasma viremia, and recent literature supports chronic immune activation as a major mechanism through which HIV affects the vascular system. ${ }^{10}$ Activated immune cells infiltrate the adventitia and adhere to the endothelium, which likely contributes to the development of vascular disease in

\footnotetext{
${ }^{1}$ Department of Medicine, Divisions of ${ }^{2}$ Infectious Diseases and ${ }^{3}$ Clinical Pharmacology, Vanderbilt University Medical Center, Nashville, Tennessee.

${ }^{4}$ Center for Vascular Biology and ${ }^{5}$ Department of Pathology, Microbiology and Immunology, Vanderbilt University Medical Center, Nashville, Tennessee.
} 
HIV-infected individuals. Prior studies have found that increased $\mathrm{T}$ cell activation is associated with carotid plaque formation and intima thickness and reduced carotid distensibility in HIV-infected patients. ${ }^{11-14}$ While the initiation of ART can improve arterial responsiveness, ${ }^{15}$ markers of endothelial cell activation often remain persistently elevated despite the suppression of plasma viremia. $6,16,17$ However, few studies have investigated how persistent innate and cellular immune activation simultaneously affect functional arterial response and endothelial activation in the context of long-term treated HIV infection.

In this study, we assessed relationships between $\mathrm{T}$ cell activation and systemic inflammation with impaired arterial response and endothelial activation in HIV-infected individuals on long-term effective ART without a known history of cardiac, vascular, or metabolic disease. The endothelial response to hypoxia was assessed using brachial artery flowmediated dilation (FMD), a functional metric associated with coronary endothelial dysfunction, progressive atherosclerosis, and cardiovascular events in the HIV-negative population. ${ }^{18-20}$ Endothelial activation was assessed using circulating intercellular adhesion molecule 1 (ICAM-1) and vascular cell adhesion molecule 1 (VCAM-1) levels, a surrogate for the expression of endothelial surface receptors that mediate the adhesion and migration of lymphocytes, monocytes, and other immune cells into the vessel wall (a process which contributes to atherosclerosis). We hypothesized that greater activation of circulating $\mathrm{T}$ cells is associated with decreased vascular responsiveness, possibly due to alterations in the T cell phenotypes present in vascular smooth muscle, while increased circulating inflammatory and macrophage activation markers would be accompanied by greater soluble ICAM-1 and VCAM-1 given the colocation and interaction of macrophages and endothelial cells in the vessel surface.

\section{Materials and Methods}

We enrolled 70 HIV-infected patients on ART from the Vanderbilt Comprehensive Care Clinic between April 2013 and September 2014. The HIV-infected subjects were distributed equally between four body mass index (BMI) categories of $<25.0,25.0-29.9,30.0-34.9$, and $\geq 35.0 \mathrm{~kg} / \mathrm{m}^{2}$. Within each BMI strata, similar numbers of males and females and whites and nonwhites were enrolled. All subjects were on efavirenz, tenofovir, and emtricitabine (i.e., the combination pill Atripla) for at least the 6 months before enrollment and had been on ART treatment with persistent HIV-1 RNA measurements $<50$ copies/ml for at least the previous 2 years. Additional inclusion criteria were $\mathrm{CD} 4^{+}$ count $>350$ cells $/ \mu$ l at the time of enrollment, no use of any antidiabetic or statin (i.e., HMG CoA reductase inhibitor) medication in the prior 6 months, no self-reported heavy alcohol (defined as $>11$ drinks/week) or cocaine/amphetamine use, no active infectious conditions aside from HIV, and no previously diagnosed diabetes, CVD, or rheumatologic disease.

All subjects fasted and abstained from tobacco for at least $8 \mathrm{~h}$, and vascular assessments were conducted between 8 and $11 \mathrm{am}$. Before any other procedures, brachial artery reactive hyperemia was measured using a Philips iE33 ultrasound with L9-3 linear transducer according to standard protocols. $^{21}$ A 3-lead ECG was attached to chest and the patient relaxed in a supine position for $10 \mathrm{~min}$. A blood pressure cuff was placed on the right forearm $1 \mathrm{~cm}$ below the antecubital fossa and the arm was extended away from body $90^{\circ}$ resting on an arm board at the height of the bed. An image of the brachial artery $3-10 \mathrm{~cm}$ above the antecubital fossa was acquired on the $E K G$ " $R$ " wave to measure the artery diameter. The cuff was inflated to $50 \mathrm{mmHg}$ above systolic pressure for 5 min. After deflation, EKG-gated measurements were acquired from still-frame images at $30,60,90$, and $120 \mathrm{~s}$. The FMD was calculated as the largest percent increase in vessel diameter after cuff deflation.

After ultrasound assessments were complete, fasting blood samples were collected. High-sensitivity C-reactive protein (hsCRP) was measured by the Vanderbilt Clinical Chemistry Laboratory. Plasma levels of soluble CD14 and CD163, two surface markers released into circulation by activated macrophages, were measured using ELISA (R\&D Systems). Serum levels of macrophage inflammatory protein-1 $\alpha$ (MIP- $1 \alpha)$, interleukin-6 (IL-6), tumor necrosis factor- $\alpha(\mathrm{TNF}-\alpha)$ receptor 1, ICAM-1, and VCAM-1 were measured in duplicate using a multiple immunoassay (Meso Scale).

$\mathrm{T}$ cell subsets were determined using flow cytometry. Peripheral blood mononuclear cells (PBMCs) were obtained from fasting whole blood samples collected in EDTA at the study visit, separated by Ficoll-Paque Plus density gradient, and cryopreserved in FBS with $10 \%$ DMSO. After study enrollment was completed, PBMC aliquots were thawed and stained with a flow cytometry panel for naive $\left(\mathrm{CD} 45 \mathrm{RO}^{-} \mathrm{CCR} 7^{+} \mathrm{CD} 27^{+}\right)$, activated $\left(\mathrm{CD} 38^{+}\right.$and $\left.\mathrm{CD} 38^{+} \mathrm{DR}^{+}\right)$, exhausted $\left(\mathrm{PD}^{+}\right)$, senescent $\left(\mathrm{CD}^{+} 7^{+}\right)$, and memory $\mathrm{T}$ cell subsets $\left(\mathrm{CD} 45 \mathrm{RO}^{+}\right)$. Cells were run on a Fortessa (Becton Dickson Biosciences) flow cytometer in the Vanderbilt Medical Center Flow Cytometry Shared Resource. The percentage of each $\mathrm{T}$ cell subset was assessed using FACSDiva software (Becton Dickson Biosciences).

\section{Statistical analyses}

Demographic and clinical characteristics were compared in a pairwise manner by sex using Wilcoxon rank sum or chisquare tests. Medians and interquartile ranges were calculated for continuous variables and percentages for categorical variables.

We assessed whether $\mathrm{T}$ cell subsets or circulating innate immune biomarkers were associated with impaired FMD or ICAM-1 and VCAM-1 using multivariate models adjusted for age, sex, BMI, smoking status (by self-report), and duration of ART. Sensitivity analyses were further individually adjusted for race, hepatitis $\mathrm{C}$ coinfection, and $\mathrm{CD} 4^{+}$count. Normality of the outcome data was assessed using Q-Q plots; based on these assessments, outcome variables were left on a linear scale for the primary analysis, but natural-log transformed for sensitivity analyses.

To aid interpretability, regression estimates are presented as standardized coefficients, in which the variances of dependent and independent variables are set equal to 1 , and the reported coefficient $\beta$ indicates how many standard deviations the outcome variable changes in response to a one standard deviation increase in the predictor variable. A $p$-value less than .05 was considered statistically significant. Because only three outcome variables were assessed and the exposure variables were grouped into a limited number of biologically distinct categories representing planned 
comparisons $\left(\mathrm{CD} 4^{+} \mathrm{T}\right.$ cells, $\mathrm{CD} 8^{+} \mathrm{T}$ cells, inflammatory biomarkers, and macrophage activation markers), we did not adjust for multiple comparisons. ${ }^{22}$ Analyses were conducted using SPSS 22.0.0 (IBM) and $R$ Statistical Software (www.R-project.org).

\section{Results}

\section{Patient demographics}

Seventy HIV-infected adults participated in the study: $43 \%$ were female and $38 \%$ were nonwhite (Table 1). The median age was 45 years (IQR 39, 50). The median $\mathrm{CD}^{+}$count at enrollment was 701 cells/ $\mu$ l (IQR 540, 954), and the mean duration of ART treatment was 6.24 years $(4.33,10.14)$. Thirty-six percent were smokers and $11 \%$ had chronic hepatitis $\mathrm{C}$ infection.

\section{Brachial artery flow-mediated dilation}

The relationships between $\mathrm{CD} 4^{+}$and $\mathrm{CD}^{+} \mathrm{T}$ cell subsets and circulating markers of inflammation and macrophage activation, with maximal brachial artery FMD were assessed in individual multivariate models (Table 2). Regression estimates are presented as standardized coefficients $(\beta)$, which indicate how many standard deviations the outcome variable changes in response to a one standard deviation increase in the predictor variable. As reference, the mean and standard deviation of predictor and outcome variables are shown in the Supplementary Table 1(Supplementary Data are available online at www.liebertpub.com/aid). The percentage of activated CD $38^{+}$ $\mathrm{CD} 8^{+} \mathrm{T}$ cells was inversely associated with $\mathrm{FMD}(p<.01)$, as

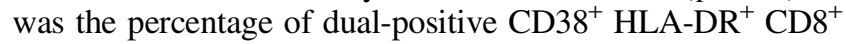
$\mathrm{T}$ cells $(p=.03)$. However, maximal FMD was not associated with the percentage of exhausted $\left(\mathrm{PD}^{+}\right)$, senescent $\left(\mathrm{CD} 57^{+}\right)$, memory $\left(\mathrm{CD} 45 \mathrm{RO}^{+}\right)$, or naive $\left(\mathrm{CD} 45 \mathrm{RO}^{-} \mathrm{CCR} 7^{+} \mathrm{CD} 27^{+}\right)$ $\mathrm{CD}^{+} \mathrm{T}$ cells. Furthermore, we did not observe a similar significant relationship between activated $\mathrm{CD}^{+} \mathrm{T}$ cells and $\mathrm{FMD}$, nor with other measured $\mathrm{CD} 4^{+} \mathrm{T}$ cell subsets.

Among the circulating biomarkers, only high sensitivity CRP was significantly associated with lower FMD $(p=.02)$. The inverse relationship between soluble CD14 and FMD approached statistical significance $(p=.05)$.

Table 1. Cohort Demographics and Clinical Characteristics

\begin{tabular}{lc}
\hline Variable & All $\mathrm{HIV+}(\mathrm{N}=70)$ \\
\hline Age, median years (IQR) & $45.0(38.8,50.0)$ \\
Female, $n(\%)$ & $30(43 \%)$ \\
Nonwhite, $n(\%)$ & $38(54 \%)$ \\
BMI, median kg/m & $30.3(23.9,35.7)$ \\
CD4 $4^{+}$at enrollment, median cells/ $\mu \mathrm{l}$ & $701(540,954)$ \\
$\mathrm{CD} 4^{+}$at ART initiation, median & $257(140,378)$ \\
$\quad$ cells $\mu$ l & $6.24(4.33,10.14)$ \\
Duration of ART treatment, & $25(36 \%)$ \\
$\quad$ median years & $8(11 \%)$ \\
Smoking, $n$ (\%) & $5.2(4.9,5.5)$ \\
Hepatitis C infection, $n(\%)$ & \\
Hemoglobin A1c &
\end{tabular}

Table 2. Multivariable Linear Regression FOR EFFECT OF IMMUNOLOGIC BIOMARKERS on Maximal Brachial Artery Flow-Mediated Dilation

\begin{tabular}{|c|c|c|}
\hline Biomarker & $\begin{array}{c}\text { Standardized } \\
\text { coefficient }(\beta) \text { for } \\
\text { maximal FMD }\end{array}$ & $\begin{array}{c}\mathrm{p}- \\
\text { value }\end{array}$ \\
\hline \multicolumn{3}{|l|}{$\mathrm{CD}^{+} \mathrm{T}$ cell markers } \\
\hline $\mathrm{CD}^{+} \mathrm{CD} 38^{+}$(activated) & -0.34 & $<.01$ \\
\hline $\mathrm{CD}^{+} \mathrm{CD} 38^{+} \mathrm{DR}^{+}$(activated) & -0.27 & .03 \\
\hline $\mathrm{CD}^{+} \mathrm{PD}^{+}{ }^{+}$(exhausted) & 0.11 & .45 \\
\hline $\mathrm{CD}^{+} \mathrm{CD}^{+} 7^{+}$(senescent) & 0.19 & .18 \\
\hline $\mathrm{CD}^{+} \mathrm{CD}^{4} 5 \mathrm{RO}^{+}$(memory) & 0.01 & .97 \\
\hline $\begin{array}{l}\mathrm{CD}^{+} \mathrm{CD} 45 \mathrm{RO}^{-} \mathrm{CCR} 7^{+} \mathrm{CD} 27^{+} \\
\text {(naive) }\end{array}$ & -0.18 & .19 \\
\hline \multicolumn{3}{|l|}{$\mathrm{CD}^{+} \mathrm{T}$ cell markers } \\
\hline $\mathrm{CD} 4^{+} \mathrm{CD} 38^{+}$(activated) & -0.08 & .59 \\
\hline $\mathrm{CD} 4^{+} \mathrm{CD} 38^{+} \mathrm{DR}^{+}$(activated) & -0.09 & .49 \\
\hline $\mathrm{CD}^{+}{ }^{+} \mathrm{PD} 1^{+}$(exhausted) & 0.22 & .10 \\
\hline $\mathrm{CD}^{+} \mathrm{CD}^{+} 7^{+}$(senescent $)$ & 0.11 & .41 \\
\hline $\mathrm{CD}^{+} \mathrm{CD}^{2} 5 \mathrm{RO}^{+}$(memory) & 0.15 & .28 \\
\hline $\begin{array}{l}\mathrm{CD}^{+} \mathrm{CD} 45 \mathrm{RO}^{-} \mathrm{CCR}^{+} \mathrm{CD} 27^{+} \\
\text {(naive) }\end{array}$ & -0.18 & .21 \\
\hline \multicolumn{3}{|l|}{ Inflammatory biomarkers } \\
\hline $\begin{array}{l}\text { High sensitivity C-reactive } \\
\text { protein }\end{array}$ & -0.32 & .02 \\
\hline Interleukin-6 & 0.14 & .30 \\
\hline TNF- $\alpha$ receptor 1 & -0.23 & .10 \\
\hline TNF- $\alpha$ receptor 2 & -0.21 & .09 \\
\hline \multicolumn{3}{|l|}{ Macrophage activation markers } \\
\hline Soluble CD14 & -0.25 & .05 \\
\hline Soluble CD163 & 0.04 & .77 \\
\hline $\begin{array}{l}\text { Macrophage Inflammatory } \\
\text { Protein- } 1 \alpha\end{array}$ & -0.18 & .16 \\
\hline
\end{tabular}

Model adjusted for age, sex, body mass index, smoking status, and duration of antiretroviral therapy.

${ }^{a}$ To aid interpretability, regression estimates have been standardized (i.e., the variances of dependent and independent variables are equal to 1), and $\boldsymbol{\beta}$ indicates how many standard deviations the dependent variable changes in response to a one standard deviation increase in the predictor variable. As reference, the mean and standard deviation of predictor and outcome variables are shown in the Supplementary Table.

$p$-values $<.05$ are shown in bold.

FMD, flow-mediated dilation; TNR- $\alpha$, tumor necrosis factor alpha.

\section{Plasma VCAM-1 and ICAM-1}

The relationships between $\mathrm{T}$ cell subsets, circulating markers of inflammation, and markers of macrophage activation with soluble VCAM-1 and ICAM-1 levels were assessed in individual multivariate models (Table 3). In contrast to the FMD analysis, higher VCAM-1 levels were associated with higher TNF- $\alpha$ receptor 1 and $2(p<.01$ for both), soluble CD163 $(p<.001)$, and macrophage inflammatory protein $1 \alpha(p=.02)$. Similarly, higher ICAM- 1 was associated with higher TNF- $\alpha$ receptor $1 \quad(p<.001)$, TNF- $\alpha$ receptor 2 $(p=.001)$, and higher soluble CD14, CD163, and macrophage inflammatory protein $1 \alpha$ ( $p<=.01$ for all).

The percentage of $\mathrm{CD} 38^{+}$activated $\mathrm{CD}^{+} \mathrm{T}$ cells was inversely associated with VCAM-1 and ICAM-1 levels in the multivariate models ( $p=.02$ and $p=.04$, respectively), but a 
Table 3. Multivariable Linear Regression for Effect of Immunologic Biomarkers ON Plasma ICAM-1 AND VCAM-1

\begin{tabular}{|c|c|c|c|c|}
\hline Biomarker & $\begin{array}{l}\text { Standardized coefficient } \\
\text { ( } \beta \text { ) for VCAM-1 }\end{array}$ & p-value & $\begin{array}{l}\text { Standardized coefficient } \\
\text { ( } \beta \text { ) for ICAM-1 }\end{array}$ & $\mathrm{p}$-value \\
\hline \multicolumn{5}{|l|}{$\mathrm{CD}^{+} \mathrm{T}$ cell markers } \\
\hline $\mathrm{CD} 8^{+} \mathrm{CD} 38^{+}$(activated) & 0.10 & .42 & 0.06 & .64 \\
\hline $\mathrm{CD}^{+} \mathrm{CD} 38^{+} \mathrm{DR}^{+}$(activated) & 0.13 & .25 & 0.06 & .65 \\
\hline $\mathrm{CD}^{+} \mathrm{PD1}^{+}$(exhausted) & 0.18 & .18 & -0.02 & .91 \\
\hline $\mathrm{CD}^{+} \mathrm{CD}^{+} 7^{+}$(senescent) & -0.11 & 40 & -0.16 & .21 \\
\hline $\mathrm{CD}^{+} \mathrm{CD} 45 \mathrm{RO}^{+}$(memory) & 0.15 & .19 & 0.01 & .99 \\
\hline $\mathrm{CD}^{+} \mathrm{CD}^{2} 5 \mathrm{RO}^{-} \mathrm{CCR} 7^{+} \mathrm{CD} 27^{+}$(naive) & 0.12 & .36 & 0.11 & .41 \\
\hline \multicolumn{5}{|l|}{$\mathrm{CD}^{+} \mathrm{T}$ cell markers } \\
\hline 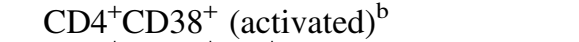 & -0.31 & .02 & -0.27 & .04 \\
\hline $\mathrm{CD} 4^{+} \mathrm{CD} 38^{+} \mathrm{DR}^{+}$(activated) & 0.13 & .25 & 0.01 & .94 \\
\hline $\mathrm{CD}^{+}{ }^{\mathrm{PD}} 1^{+}$(exhausted) & 0.12 & .33 & 0.02 & .88 \\
\hline $\mathrm{CD}^{+} \mathrm{CD}^{+} 7^{+}$(senescent) & 0.01 & .98 & 0.02 & .85 \\
\hline $\mathrm{CD}^{+}{ }^{+} \mathrm{CD} 45 \mathrm{RO}^{+}$(memory) & 0.29 & .02 & 0.11 & .38 \\
\hline $\mathrm{CD}^{+}{ }^{+} \mathrm{CD} 45 \mathrm{RO}^{-} \mathrm{CCR} 7^{+} \mathrm{CD} 27^{+}$(naive) & 0.09 & .49 & -0.06 & .68 \\
\hline \multicolumn{5}{|l|}{ Inflammatory biomarkers } \\
\hline High sensitivity C-reactive protein & -0.13 & .31 & 0.08 & .55 \\
\hline Interleukin-6 & 0.15 & .25 & 0.20 & .12 \\
\hline TNF- $\alpha$ receptor 1 & 0.46 & $<.001$ & 0.49 & $<.001$ \\
\hline TNF- $\alpha$ receptor 2 & 0.30 & $<.01$ & 0.37 & .001 \\
\hline \multicolumn{5}{|l|}{ Macrophage activation markers } \\
\hline Soluble CD14 & 0.12 & .33 & 0.31 & .01 \\
\hline Soluble CD163 & 0.41 & $<.001$ & 0.30 & $<.01$ \\
\hline Macrophage Inflammatory Protein- $1 \alpha$ & 0.28 & .02 & 0.39 & .001 \\
\hline
\end{tabular}

Model adjusted for age, sex, body mass index, smoking status, and duration of antiretroviral therapy.

$n=70$ HIV+ subjects.

${ }^{\text {a }}$ To aid interpretability, regression estimates have been standardized (i.e., the variances of dependent and independent variables are equal to 1), and $\boldsymbol{\beta}$ indicates how many standard deviations the dependent variable changes in response to a one standard deviation increase in the predictor variable. As reference, the mean and standard deviation of predictor and outcome variables are shown in the Supplementary Table.

${ }^{\mathrm{b}}$ Because $\mathrm{CD} 38$ may also be expressed on naive $\mathrm{CD}^{+} \mathrm{T}$ cells at moderate levels, we separated $\mathrm{CD} 4^{+} \mathrm{CD}^{+} 8^{+} \mathrm{T}_{\text {cells }}$ into $\mathrm{CD}^{+} 5 \mathrm{RO}^{+}$(nonnaive) and CD45RO-negative subsets and found that $\mathrm{CD}^{+} \mathrm{CD} 45 \mathrm{RO}^{+} \mathrm{CD} 38^{+}$non-naive T cells were not associated with either ICAM-1 or VCAM-1. However, CD4 ${ }^{+} \mathrm{CD} 45 \mathrm{RO}^{-} \mathrm{CD} 38^{+} \mathrm{T}$ cells remained inversely associated with ICAM- 1 in the adjusted model $(\beta=-0.25 ; p<.04)$, although not with VCAM-1 $(p=.15)$. This finding suggests that the presence of naive, CD38 mono-expressing CD4 ${ }^{+} \mathrm{T}_{\text {cells may }}$ underlie our finding of an inverse statistical relationship between ICAM-1/VCAM-1 and CD $38^{+} \mathrm{CD} 4^{+} \mathrm{T}$ cells as a group.

$p$-values $<.05$ are shown in bold.

ICAM-1, intercellular adhesion molecule 1; TNR- $\alpha$, tumor necrosis factor alpha; VCAM-1, vascular cell adhesion molecule 1.

similar association was not observed for the dual-positive $\mathrm{CD} 38^{+} \mathrm{DR}^{+} \mathrm{CD} 4^{+}$cells. In contrast, a higher percentage of memory $\mathrm{CD} 4^{+} \mathrm{T}$ cells was associated with a higher VCAM-1 level $(p=.02)$, but not ICAM-1 level $(p=.38)$. The finding that the directionality of the association between VCAM-1 and $\mathrm{CD} 38$ mono-expressing $\mathrm{CD}^{+}$cells was opposite the directionality for memory $\mathrm{CD} 4^{+} \mathrm{T}$ cells was unexpected, and because $\mathrm{CD} 38$ may also be expressed on naive $\mathrm{CD} 4^{+} \mathrm{T}$ cells at moderate levels, we investigated this relationship further. ${ }^{23}$ We separated $\mathrm{CD}^{+} \mathrm{CD}^{+} 8^{+} \mathrm{T}$ cells into $\mathrm{CD} 45 \mathrm{RO}^{+}$(nonnaïve) and $\mathrm{CD}^{2} 4 \mathrm{RO}^{-}$subsets and found that $\mathrm{CD} 4^{+} \mathrm{CD} 45 \mathrm{RO}^{+}$ $\mathrm{CD}^{2} 8^{+}$non-naive $\mathrm{T}$ cells were not associated with either ICAM-1 or VCAM-1. However, CD $4^{+} \mathrm{CD}_{5} \mathrm{RO}^{-} \mathrm{CD} 38^{+}$ $\mathrm{T}$ cells remained inversely associated with ICAM- 1 in the adjusted model $(\beta=-0.25 ; p<.04)$, although not with VCAM-1 $(p=.15)$. This finding suggests that the presence of naive, CD38 mono-expressing $\mathrm{CD} 4^{+} \mathrm{T}$ cells may underlie our finding of an inverse statistical relationship between ICAM-1/ VCAM- 1 and $\mathrm{CD} 38^{+} \mathrm{CD} 4^{+} \mathrm{T}$ cells as a group.

Finally, there were no significant associations observed between $\mathrm{CD}^{+} \mathrm{T}$ cell subsets and plasma ICAM-1 or VCAM- 1 . Results for all models were similar when adjusted for race, hepatitis $\mathrm{C}$ status, and $\mathrm{CD}^{+}$count. The statistically significant relationships persisted when FMD, VCAM-1, and ICAM-1 were natural-log transformed, and there was minimal change in the standardized regression coefficients.

\section{Discussion}

In HIV-infected adults on long-term ART with sustained virologic suppression, $\mathrm{CD} 8^{+} \mathrm{T}$ cell activation (but not $\mathrm{CD} 4^{+}$ $\mathrm{T}$ cell or monocyte activation) was associated with a reduced brachial artery response following the reversal of ischemia, consistent with the hypothesis that activated $\mathrm{CD} 8^{+} \mathrm{T}$ cells may contribute to impaired smooth muscle relaxation independent of other cardiovascular risk factors. We additionally observed persistent inflammation and endothelial activation in this cohort and observed an association of higher VCAM-1 and ICAM-1 levels with soluble TNF- $\alpha$ receptors and macrophage activation markers. This finding suggests that prior observations linking chronic low-grade inflammation in treated HIV infection to increased CVD risk may reflect, in part, a link between chronic macrophage and endothelial cell activation. Our findings support prior studies showing an 
association between HIV and vascular stiffness. ${ }^{24-26}$ However, unlike these earlier studies which frequently included patients with a detectable viral load and relatively short duration of ART therapy, we observed a persistence of this relationship despite more than 2 years of uniform viral suppression in our cohort.

This study utilized brachial artery FMD, a functional measure of arterial response to hypoxia, and some of our findings differ from recent studies of carotid artery distensibility in HIV-infected persons. While we did not observe an association between $\mathrm{CD}^{+}{ }^{\mathrm{T}}$ cell or monocyte activation with decreased brachial artery FMD, an analysis of the Women's Interagency HIV Study (WIHS) found that higher CD $4^{+} \mathrm{T}$ cell activation was associated with increased vascular stiffness, although brachial FMD was not assessed. ${ }^{12,13}$ However, the WIHS analysis of HIV positive women included a proportion of participants either not on ART or with detectable viremia at the time of study, while all of our participants were on the same ART regimen with consistent viral suppression. ${ }^{12}$

Activated T cells remain approximately twofold higher in ART-treated HIV-infected individuals compared to noninfected persons, ${ }^{27}$ and it is possible that the long duration of viral suppression in our cohort (minimum of 2 years) and ART treatment (median 6.8 years in our cohort) may have engendered a $\mathrm{T}$ cell subset phenotype, in which $\mathrm{CD}^{+} \mathrm{T}$ cell activation was more representative of ongoing antigenic stimulation compared to $\mathrm{CD}^{+}$activation. This theory is supported by several prior studies by Catalfamo et al. which have shown clear differences in activated $\mathrm{T}$ cell subsets in patients with HIV infection over time. The level of $\mathrm{CD} 4^{+} \mathrm{T}$ cell activation in chronic HIV infection likely reflects a homeostatic proliferation around a relatively constant value, while ongoing, chronic antigen stimulation remains the primary driver for $\mathrm{CD}^{+} \mathrm{T}$ cell activation. $^{28,29}$ The sustained activation of $\mathrm{CD}^{+}$cells is likely due to a complex interplay of factors in the absence of plasma viremia, and elucidating the $\mathrm{CD}^{+}$antigenic stimuli could inform our understanding of how the arterial lining and smooth muscle are affected by cellular immune processes in both HIVinfected and uninfected individuals.

In contrast to our brachial FMD results, we found that soluble markers of endothelial activation were primarily associated with macrophage activation, likely reflecting the interaction of macrophages and endothelial cells within the vascular structures. The formation of atherosclerotic plaques is due, in part, to activation of the endothelial lining, leading to the accumulation of monocytes and other inflammatory cells in the vessel walls, which can ultimately become necrotic and unstable leading to rupture. ${ }^{30,31}$ Endothelial activation and VCAM-1 and ICAM-1 expression are essential to plaque formation by tethering circulating leukocytes and facilitating transendothelial cell migration. However, soluble ICAM-1 also independently promotes a pro-inflammatory response in diverse tissues, including a role in monocyteendothelial cell interactions, likely potentiating the development of atherosclerosis and other chronic inflammatory diseases. ${ }^{32-35}$ Our results show that this interplay between innate immune activation and endothelial activation primarily studied in HIV-negative persons is also present in $\mathrm{HIV}$-infected persons, which is of concern given the persistent inflammation in HIV patients despite effective ART. ${ }^{6,36}$

Strengths of this study included an uniform ART treatment regimen in all $\mathrm{HIV}$-infected subjects, the exclusion of sub- jects with known CVD or diabetes, a minimum 2-year period of virologic suppression to allow the effects of plasma viremia to fade, and a required minimum $\mathrm{CD}^{+} \mathrm{T}$ cell count ( $>350 \mathrm{CD}^{+}$cells $\left./ \mu \mathrm{l}\right)$. Limitations of the study include a relatively small sample size and cross-sectional design, which prevents assessment of causality and variability of dependent variables over time. Because all participants were on the regimen of efavirenz, tenofovir, and emtricitabine, additional studies are needed before extrapolating our results to patients on a protease inhibitor or the increasingly common integrase inhibitors.

In summary, our study found that $\mathrm{T}$ cell and macrophage activation appear to impact distinct processes or mechanisms in the vasculature of HIV-infected individuals, and thus, cardiovascular risk assessments should include both functional and biomarker measurements. Defining the relationships between immune activation, inflammation, and vascular health are important to reducing the burden of CVD in HIV-infected persons with long-term viral suppression on ART. Further studies are clearly needed to understand the mechanistic links between $T$ cell activation and vascular function, and the source of the chronic monocyte/macrophage stimuli contributing to endothelial activation.

\section{Acknowledgments}

The authors thank the participants in the Adiposity and Immune Activation Cohort study.

This work was supported by NIAID [grant numbers K23 100700 and K24 AI65298], the NIH-funded Vanderbilt Clinical and Translational Science award from NCRR/NIH [grant number UL1 RR024975-01], and the NIH-funded Tennessee Center for AIDS Research [grant number P30 AI110527]. The Vanderbilt University Flow Cytometry Shared Resource is supported by the Vanderbilt Ingram Cancer Center (P30 CA68485) and the Vanderbilt Digestive Disease Research Center (DK058404). The funders had no role in study design, data collection and analysis, decision to publish, or preparation of the article.

Presented at the Conference on Retroviruses and Opportunistic Infections (CROI); February 24, 2016; Boston, Massachusetts.

\section{Author Disclosure Statement}

No competing financial interests exist.

\section{References}

1. Currier JS, Taylor A, Boyd F, et al.: Coronary heart disease in HIV-infected individuals. J Acquir Immune Defic Syndr 2003;33:506-512.

2. Triant VA, Lee H, Hadigan C, Grinspoon SK: Increased acute myocardial infarction rates and cardiovascular risk factors among patients with human immunodeficiency virus disease. J Clin Endocrinol Metab 2007;92:2506-2512.

3. Cruse B, Cysique LA, Markus R, Brew BJ: Cerebrovascular disease in HIV-infected individuals in the era of highly active antiretroviral therapy. J Neurovirol 2012;18:264-276.

4. Freiberg MS, Chang CC, Kuller LH, et al.: HIV infection and the risk of acute myocardial infarction. JAMA Intern Med 2013;173:614-622. 
5. Womack JA, Chang CC, So-Armah KA, et al:: HIV infection and cardiovascular disease in women. J Am Heart Assoc 2014;3:e001035.

6. Ronsholt FF, Ullum H, Katzenstein TL, Gerstoft J, Ostrowski SR: Persistent inflammation and endothelial activation in HIV-1 infected patients after 12 years of antiretroviral therapy. PLoS One 2013;8:e65182.

7. Subramanian $\mathrm{S}$, Tawakol A, Burdo TH, et al:: Arterial inflammation in patients with HIV. JAMA 2012;308:379-386.

8. Hsue PY, Giri K, Erickson S, et al:: Clinical features of acute coronary syndromes in patients with human immunodeficiency virus infection. Circulation 2004;109:316319.

9. Pober JS, Sessa WC: Evolving functions of endothelial cells in inflammation. Nat Rev Immunol 2007;7:803-815.

10. Haser GC, Sumpio B: Systemic and cell-specific mechanisms of vasculopathy induced by human immunodeficiency virus and highly active antiretroviral therapy. J Vasc Surg 2016. [Epub ahead of print]; DOI:10.1016/j.jus.2016 .01 .036 .

11. Kaplan RC, Sinclair E, Landay AL, et al.: T cell activation and senescence predict subclinical carotid artery disease in HIV-infected women. J Infect Dis 2011;203:452-463.

12. Kaplan RC, Sinclair E, Landay AL, et al.: T cell activation predicts carotid artery stiffness among HIV-infected women. Atherosclerosis 2011;217:207-213.

13. Karim R, Mack WJ, Kono N, et al.: T-cell activation, both pre- and post-HAART levels, correlates with carotid artery stiffness over 6.5 years among HIV-infected women in the WIHS. J Acquir Immune Defic Syndr 2014;67:349-356.

14. Longenecker CT, Funderburg NT, Jiang Y, et al:: Markers of inflammation and CD8 T-cell activation, but not monocyte activation, are associated with subclinical carotid artery disease in HIV-infected individuals. HIV Med 2013;14:385-390.

15. Torriani FJ, Komarow L, Parker RA, et al.: Endothelial function in human immunodeficiency virus-infected antiretroviral-naive subjects before and after starting potent antiretroviral therapy: The ACTG (AIDS Clinical Trials Group) Study 5152 s. J Am Coll Cardiol 2008;52:569-576.

16. de Larranaga GF, Bocassi AR, Puga LM, Alonso BS, Benetucci JA: Endothelial markers and HIV infection in the era of highly active antiretroviral treatment. Thromb Res 2003;110:93-98.

17. de Gaetano Donati K, Rabagliati R, Tumbarello M, et al.: Increased soluble markers of endothelial dysfunction in HIV-positive patients under highly active antiretroviral therapy. AIDS 2003; 17:765-768.

18. Faulx MD, Wright AT, Hoit BD: Detection of endothelial dysfunction with brachial artery ultrasound scanning. Am Heart J 2003;145:943-951.

19. Juonala M, Viikari JS, Laitinen $\mathrm{T}$, et al:: Interrelations between brachial endothelial function and carotid intimamedia thickness in young adults: The cardiovascular risk in young Finns study. Circulation 2004;110:2918-2923.

20. Shechter M, Shechter A, Koren-Morag N, Feinberg MS, Hiersch L: Usefulness of brachial artery flow-mediated dilation to predict long-term cardiovascular events in subjects without heart disease. Am J Cardiol 2014;113:162167.

21. Corretti MC, Anderson TJ, Benjamin EJ, et al:: Guidelines for the ultrasound assessment of endothelial-dependent flow-mediated vasodilation of the brachial artery: A report of the International Brachial Artery Reactivity Task Force. J Am Coll Cardiol 2002;39:257-265.
22. Savitz DA, Olshan AF: Multiple comparisons and related issues in the interpretation of epidemiologic data. Am J Epidemiol 1995;142:904-908.

23. Benito JM, Lopez M, Lozano S, et al.: Differential upregulation of CD38 on different T-cell subsets may influence the ability to reconstitute CD4+ T cells under successful highly active antiretroviral therapy. J Acquir Immune Defic Syndr 2005;38:373-381.

24. Stein JH, Klein MA, Bellehumeur JL, et al:: Use of human immunodeficiency virus-1 protease inhibitors is associated with atherogenic lipoprotein changes and endothelial dysfunction. Circulation 2001;104:257-262.

25. van Wijk JP, de Koning EJ, Cabezas MC, et al.: Functional and structural markers of atherosclerosis in human immunodeficiency virus-infected patients. J Am Coll Cardiol 2006;47:1117-1123.

26. Solages A, Vita JA, Thornton DJ, et al.: Endothelial function in HIV-infected persons. Clin Infect Dis 2006;42:13251332.

27. Hunt PW, Brenchley J, Sinclair E, et al:: Relationship between $\mathrm{T}$ cell activation and CD4+ $\mathrm{T}$ cell count in HIVseropositive individuals with undetectable plasma HIV RNA levels in the absence of therapy. J Infect Dis 2008;197:126133.

28. Catalfamo M, Di Mascio M, Hu Z, et al:: HIV infectionassociated immune activation occurs by two distinct pathways that differentially affect CD4 and CD8 T cells. Proc Natl Acad Sci U S A 2008;105:19851-19856.

29. Catalfamo M, Wilhelm C, Tcheung L, et al.: CD4 and CD8 $\mathrm{T}$ cell immune activation during chronic HIV infection: Roles of homeostasis, HIV, type I IFN, and IL-7. J Immunol 2011;186:2106-2116.

30. Ross R: Atherosclerosis is an inflammatory disease. Am Heart J 1999;138:S419-S420.

31. Andersson J, Libby P, Hansson GK: Adaptive immunity and atherosclerosis. Clin Immunol 2010;134:33-46.

32. Schmal H, Czermak BJ, Lentsch AB, et al.: Soluble ICAM-1 activates lung macrophages and enhances lung injury. J Immunol 1998;161:3685-3693.

33. Lukacs NW, Strieter RM, Elner VM, Evanoff HL, Burdick M, Kunkel SL: Intercellular adhesion molecule-1 mediates the expression of monocyte-derived MIP-1 alpha during monocyteendothelial cell interactions. Blood 1994;83:1174-1178.

34. McCabe SM, Riddle L, Nakamura GR, et al:: sICAM-1 enhances cytokine production stimulated by alloantigen. Cell Immunol 1993;150:364-375.

35. Otto VI, Heinzel-Pleines UE, Gloor SM, Trentz O, Kossmann T, Morganti-Kossmann MC: sICAM-1 and TNFalpha induce MIP-2 with distinct kinetics in astrocytes and brain microvascular endothelial cells. J Neurosci Res 2000;60:733-742.

36. Francisci D, Giannini S, Baldelli F, et al:: HIV type 1 infection, and not short-term HAART, induces endothelial dysfunction. AIDS 2009;23:589-596.

Address correspondence to: John R. Koethe

Division of Infectious Diseases Vanderbilt University Medical Center A2200-MCN

116121 st Avenue South Nashville, TN 37232-2582

E-mail: john.r.koethe@vanderbilt.edu 